\title{
Extract of Caesalpinia sappan L. as Antibacterial Feed Additive on Intestinal Microflora of Laying Quail
}

\author{
Anang Widigdyo ${ }^{1 *}$, Eko Widodo ${ }^{2}$, Irfan Hadji Djunaidi ${ }^{2}$ \\ ${ }^{1}$ Master Program of Animal Husbandry, Faculty of Animal Husbandry, University of Brawijaya, Malang, Indonesia \\ ${ }^{2}$ Department of Animal Husbandry, Faculty of Animal Husbandry, University of Brawijaya, Malang, Indonesia
}

\begin{abstract}
Caesalpinia sappan L. is a phytobiotic plant that serves as an antibacterial. Active compound such as flavonoids in the $C$. sappan L. extract acts as an antibacterial. The protein food sources in Indonesia including poultry such as quail. Several studies demonstrated that quail are very susceptible to bacterial infections including Escherichia coli and Salmonella. Thus $C$. sappan has been used as food additive for quail in laying eggs. This research objective was to study the effects of $C$. sappan L. extract against intestinal miclofora of quail in laying eggs. This study used 168 quails with 4 treatments and 5 replications, each treatment used 7 quails. This study used 4 Wood Extract $C$. sappan L. treatment with different concentrations including $0 \%, 0.2 \%, 0.4 \%, 0.6 \%$. The results showed that administration of Extract Wood C. sappan L. was not significantly different $(P>0.05)$ to the total number of bacteria $E$. coli with the average $\mathrm{P}_{0}\left(6.0903\right.$ Log CFU), $\mathrm{P}_{1}$ (6.0903 log CFU), $P_{2}\left(6.0887\right.$ Log CFU), and $P_{3}(6.0868$ Log CFU). Meanwhile it was significantly different $(P<0.05)$ to the total number of Salmonella bacteria in the gut laying with the average number of bacteria $\mathrm{P}_{0}\left(5.4059 \log\right.$ CFU), $\mathrm{P}_{1}$ (5.4048 Log CFU), $P_{2}$ (5.4045 Log CFU), and $P_{3}$ (5.4039 Log CFU). It is concluded that flavonoids compounds in C. sappan $L$. extract could decrease the number of Salmonella, but not $E$. coli, in the intestine of quail.
\end{abstract}

Keywords: Caesalpinia sappan L., Escherichia coli, Flavonoid, Salmonella.

\section{INTRODUCTION}

Caesalpinia sappan $\mathrm{L}$. is a medicinal plant that has been used as a healthy drink product in Indonesia. The boiled wood shavings of Caesalpinia is usually used and mixed with other ingredients/herbs serves as a hot drink. In the previous experiment, $C$. sappan L. qualitatively contained flavonoid [1]. Other active compounds included tannins, polyphenols, kardeno-lin, anthraquinone, sappan chalcone, caesalpin, resin, resonin, brazillin, d-alpha phallandren, osaemenan, and essential oil [2]. The active compounds of $C$. sappan $\mathrm{L}$. have antiinflammatory properties, antiproliteratif, anticoagulants, anti-virus, anti-oxidants [3], immunostimulant, anticonvulsants [4] and antimicrobial properties [5]. Thus, the flavonoid of $C$. sappan L. could be used as a feed additive to modify intestinal microflora of quail at laying periods.

Quail is one of the productive poultry species which could produce 250-300 eggs per year [6], a nutritious protein source for human. Bad environmental condition and biosecurity cause quail is easily infected with pathogenic bacteria.

\footnotetext{
* Correspondence author:

Anang Widigdyo

Email : anangwidigdyo@yahoo.com

Address : Department of Animal Husbandry, University of Brawijaya, Jl. Veteran Malang, 65145
}

The synthetic antibiotics are usually used to solve the problem. However, the prolong use of antibiotics may have a negative effect for the quail. The previous study reported that the long term use of antibiotics causes of bacterial resistant [7]. One alternative is to replace the use of synthetic antibiotic by using wood extract of $C$. sappan L. Therefore, the current research was intended to determine flavonoid content and effect of $C$. sappan L. on intestinal micro-flora of laying Japanese quail.

\section{MATERIALS AND METHODS \\ Preparation of Caesalpinia sappan L. Extract}

One kg powder of Caesalpinia sappan L. produced by UPT of Materia Medica, Batu Malang was diluted with $5 \mathrm{~L}$ of $90 \%$ ethanol. It was then macerated for $4 \times 24$ hours. Furthermore, the filtrate was separated, and extracted by using soxhlet destilation apparatus for 18 hours. Unlike what has been done previously [5], this current destilation was done once and the result obtained was $20 \mathrm{ml}$ wood extract of $C$. sappan $\mathrm{L}$.

\section{Procedure to Determine Flavonoid Compounds in the Wood Extract of Caesalpinia sappan $L$.}

Wood extract of $C$. sappan L.as much as $5 \mathrm{ml}$ was heated for 5 minutes, then was added with a few drops of concentrated $\mathrm{HCl}$ and a little Magnesium powder, stirred well by hand. A 
positive test result was indicated by the appearance of a dark red or pink.

\section{Experiment on Intestinal Microflora of Quail}

This materials of study consisted of 168 laying quails of 10 weeks old, wood extract of $C$. sappan L. In addition, some feed ingredients also used namely yellow corn, soybean meal, fish meal (CP $50 \%), \mathrm{MBM}, \mathrm{CaCO}_{3}$, Methionine, L-Lysine, Coconut Cake meal, Pollard, Premix, and Di Calcium Phospate. The result of proximate analysis of feed used in the study was described in Table 1.

\begin{tabular}{lc}
\multicolumn{2}{l}{ Table 1. Feed Chemical } \\
\hline Chemical contents & Contents \\
\hline Crude Protein & $21.90 \%$ \\
Gross Energy & $3692 \mathrm{Kcal} / \mathrm{Kg}$ \\
Fiber & $3.18 \%$ \\
Fat & $6.51 \%$ \\
Calsium & $2.55 \%$ \\
Phospor & $0.70 \%$ \\
\hline
\end{tabular}

Source: Division Livestock Nutrition Laboratory of Blitar (2017).

The feed was given twice a day, morning and evening, with the respective proportion of $40 \%$ to $60 \%$. The feed was offered 26 g.bird $^{-1}$ day $^{-1}$, while water was given ad libitum. The used method was experiment, arranged in Completely Randomized Design (CRD) with 4 treatments and 5 replications. Each treatment consisted of 7 quails. The treatments were quail as follows:

$$
\begin{aligned}
& P_{0}=\text { Basal feed }(\text { Control) } \\
& P_{1}=\text { Basal feed }+0.2 \% \text { extract of } C \text {. sappan } L . \\
& P_{2}=\text { Basal feed }+0.4 \% \text { extract of } C \text {. sappan } L . \\
& P_{3}=\text { Basal feed }+0.6 \% \text { extract of } C \text {. sappan } L .
\end{aligned}
$$

Variables observed in this study were the total number of Escherichia coli and Salmonella taken from ileum of quail at 16 weeks of age. The numbers of bacterial colonies were counted by using Gariga method [8].

\section{Data Analisys}

Data were statistically analyzed by ANOVA test of Completely Randomized Design and if significantly different effect appears then followed by Duncan's Multiple Range Test.

\section{RESULT AND DISCUSSION}

\section{Qualitative Determination of Flavonoid}

Qualitative analysis of flavonoid compounds showed that wood extract of $C$. sappan $\mathrm{L}$. positively contained reasonable concentration of flavonoid indicated by appearance of dark red color. The previous study also reported similar result [1], and also reported that strong antioxidant activity of extracts of $C$. sappan $\mathrm{L}$. is positively correlated to the concentration of total phenol and flavonoid. It is showed in Figure 1.

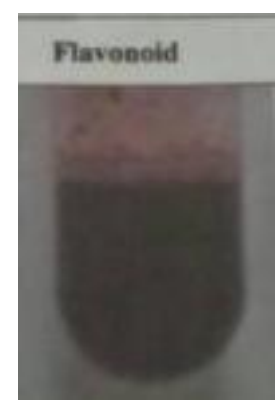

Figure 1. A dark brown colour showed when detected flavonoid was qualitatively analysis

\section{Effect of Treatment on Microbial Population}

Effect of different levels of wood extract of $C$. sappan L. on microbial population in the quail intestinal tract was described in Table 2.

Table 2. Effect of Treatment on Escherichia coli and Salmonella Population

\begin{tabular}{ccc}
\hline \multirow{2}{*}{ Treatment } & \multicolumn{2}{c}{ Total Colonies of Bacteria ( Log CFU) } \\
\cline { 2 - 3 } & Escherichia coli & Salmonella \\
\hline$P_{0}$ & $6.090 \pm 0.003$ & $5.406 \pm 0,001^{a}$ \\
$P_{1}$ & $6.090 \pm 0.003$ & $5.405 \pm 0,001^{b}$ \\
$P_{2}$ & $6.089 \pm 0.002$ & $5.404 \pm 0,001^{c}$ \\
$P_{3}$ & $6.087 \pm 0.003$ & $5.404 \pm 0,001^{c}$ \\
\hline
\end{tabular}

Description: different Superscrib in the same column indicated significant different $(P<0.05)$

Feeding different levels of $C$. sappan L. wood extract as feed additive did not significantly change $(P>0.05)$ total colonies of $E$. coli, but significantly decreased $(P<0.05)$ the number of Salmonellla in ileal digesta of quail.

The result data showed that extract of $C$. sappan L. could decrease total colony of $E$. coli and Salmonella. The total decrease of bacterial colony is caused by flavonoid compound in $C$. sappan L. [3]. Flavonoids undermine the permeability of bacterial cell membranes that result in the membrane sitplasma into lysis [9].

\section{Effect of Graded Levels of Caesalpinia sappan $L$. Wood Extract on Population of Eshericia coli}

The result presented in Table 2 showed that the respective average values of TPC of $E$. coli from the highest to the lowest, i.e. $P_{0}, P_{1}, P_{2}$ and $\mathrm{P}_{3}$. The highest number of colonies of $E$. coli was for $P_{0}(6.090 \pm 0.003$ Log CFU) and the lowest was for $\mathrm{P}_{3}(6.087 \pm 0.003$ Log CFU). Statistical analysis showed that wood extract of $C$. sappan $\mathrm{L}$. did not 


$$
\text { (Widigdyo et al.) }
$$

significantly change ( $\mathrm{P}>0.05)$ the population of $E$. coli.

Theoretically, the antibacterial compound of flavonoid in the wood extract of $C$. sappan L. could combat the pathogenic bacteria such as $E$. coli. But the research data in Table 2 showed no reduction in $E$. coli population in the small intestine of quail. One of the reasons was the cell wall of E. coli is thicker than Salmonella, leading to difficulty in disrupting the wall because flavonoids could not penetrate the cell wall of $E$. coli [10]. Lipid content of the cell wall of E. coli (11-24\%) was thicker than than of Salmonella (14\%) may contribute to the difficulty of flavonoids to penetrate the cell wall. So, it might need higher concentration of flavonoid to kill $E$. coli [10]. This is also supported bu another study that formation of inhibition zone against $E$. coli because of giving the same concentration of $C$. sappan $L$. wood extract solution was smaller than that of Salmonella $(9.0 \pm 0.7 \mathrm{~mm}$ vs $20 \pm 1.3 \mathrm{~mm})$ [11].

\section{Effect of Graded Levels of Caesalpinia sappan L.} Wood Extract on population of Salmonella

Table 2 showed that the use of wood extract of $C$. sappan $L$. as quail feed additive significantly increased $(P<0.05)$ the number of colonies of Salmonella in the intestine. The averages of colonies of Salmonella were consecutively $\mathrm{P}_{0}$ $\left(5.406 \pm 0.001^{\mathrm{a}}\right) ; P_{1}\left(5.405 \pm 0.001^{\mathrm{b}}\right) ; P_{2}(5.405 \pm$ $\left.0.001^{\mathrm{b}}\right)$; and $\mathrm{P}_{3}\left(5.404 \pm 0.001^{\mathrm{C}}\right)$. The results showed that the highest level of wood extract of C. sappan L. gave the lowest number of colonies of Salmonella in the intestine of quail. This indicated that at the highest concentration of the extract which also means highest level of flavonoid, could effectively disrupt the cell wall of Salmonella leading to decrease its population in the intestine of laying quail. Changes in organic components and transport nutrients metabolism by the bacteria occurred due to disruption of the hydroxyl groups of flavonoid compounds. Flavonoid compounds also inhibit topoisomerase II (DNA gyrase) enzyme, an important enzyme in the process of bacterial DNA replication and transcription [12].

The decline in the number of colonies of Salmonella bacteria in the intestine caused by the content of quail flavonoids, phenols, and brazilin on wood extract $C$. sappan L. flavonoids decrease the number of colonies of bacteria by destroying the bacterial cell wall, microsomes and lysosomes as a result of the interaction of flavonoids with bacterial DNA. Flavonoids inhibit the growth of bacterial cells by disrupting the bacterial cell nutrient transport processes that lead to decreased metabolism so that the proliferation and growth of bacteria becomes inhibited [13]. Flavonoid activity can damage the cell wall of bacteria is also due to be lipophilic, which work to form complex bonds with extracellular proteins [14].

\section{CONCLUSION}

It is concluded that wood extract of Caesalpinia sappan L. is qualitatively contains flavonoid and showed antibacterial effect due to ability of reducing colonies of Salmonella in the laying quail intestine. This may attribute to the flavonoid may act to disrupt cell wall of Salmonella.

\section{REFERENCES}

[1] Widowati, W. 2011. Uji fitokimia dan potensial antioksidan ekstrak kayu Secang (Caesalpinia sappan L.). Jurnal Kesehatan Masyarakat. I(1). 23-31.

[2] Karlina, Y., A. Putranti, M.A. Dewi, L.F. Nurul, M. Desi. 2016. Pengujian potensi anti jamur ekstrak kayu Secang terhadap Aspregilus dan Cadinda albicans. Chimica et natura. 4(2): 84-87.

[3] Badami, S., S. Moorkorn, S.R. Rali, E. Kannan, S. Bhojrong. 2003. Antioxidan activity of Caesalpinia sappan L. Heart Wood. Biol. Pharm. Blull. 26. 1534-1537.

[4] Baek, N.I., S.G. Jeon, E.M. Ahn, J.T. Hanhn, S.W. Cho. 2002. Ancovasculant compounds from the wood of Caesalpinia sappan L. Arch. Pharm. Res. 23. 344-348.

[5] Xu, H.X., S.F. Lee. 2004. The antibacterial principle of Caesalpinia sappan L. Phytother. Res. 18.647-651.

[6] Subekti, E., H. Dewi. 2013. Budidaya Puyuh (Coturnix coturnix Japonica) di pekarangan sebagai sumber protein hewani dan penambah income keluarga. Mediagro. 2(1). 1-10.

[7] Darma, B., S. I Wayan, M. Hapsari. 2013. Efektivitas perasan akar Kelor (Moringa oleifera) sebagai pengganti antibiotik pada ayam broiler yang terkena kolibasilosis. Indonesia Medalpiniaiases Veterinus. 2(3). 331-346.

[8] Gariga, M., M. Pascual, J.M. Monfort, M. Hugas. 1998. Selection of Lactobaccili for chicken probiotic adjuncts. J. Appl. Microbiol. 84. 125-132. 
[9] Suteja, I.K.P, S.R. Wiwik, I.G.G. Wayan. 2016. Identification and activity test compound flavonoid from extract of leave Trembesi (Albiza saman M.) as antibacterial of Escherichia coli. J. Chem. 10(1). 141-148.

[10] Noventi, W., N. Carolia. 2016. Potensi ekstrak daun Sirih Hijau (Piper betle L.) sebagai alternatif terapi acne vulgaris. Mayority. 5(1). 140-145.

[11] Srinivasan, R., G.S. Govinderasu, K. Saktivol, M. Krishnamurty, B. Ramaiya, K. Mariappan, G. Muchukatan. 2012. In vitro antimicrobial activity of Caesalpinia sappan L. Asian Pasific J. Trop. Biomed. S136-S139.

[12] Sanarto, S., R. Rita, S.M. Debby. 2011. Uji Efektifitas Ekstrak Sirih Merah (Piper erocatum) Sebagai Anti Mikroba Terhadap Bakteri Klebsiella pneumonia. Available at: http://old.FK.ub.ac,id/index.html.

[13] Retnowati, Y., B. Nurhayati, W.P. Nona. 2011. Pertumbuhan Bakteri Staphylococcus aureus Pada Media Yang Di Ekspos Dengan Infus Daun Sambiloto (Andrographis paniculata). Saintek. 6(2). 1-9.

[14] Dini, I., Muharram, F. Sitti. 2011. The potential of Tembelekan Plant (Lantana camar Linn.) extract to inhibited the growth of Staphylococcus aureus and Eschericia coli. Bionature. 12(1). 21-25. 